Original Paper

Special Articles: Biomass

特集：バイオマス

\title{
Application of Cold-tolerant Marine diatom, Mayamaea sp. JPCC CTDA0820 to Low-Energy Cultivation Process for Stable Biodiesel Production
}

\author{
Mitsufumi Matsumoto ${ }^{* 1}$, Daisuke Nojima *2, Kiichi IKedA ${ }^{* 2}$, \\ Tomoko Yoshino *2, and Tsuyoshi TANAKA *2
}

(Received February 13, 2015)

\section{通年バイオディーゼル燃料生産に向けた低温耐性海洋珪藻 Mayamaea 属 JPCC CTDA08020 株の 低エネルギー化プロセスへの適応}

松本光史 ${ }^{*}$, 野島大佑 ${ }^{*}$, 池田貴一 ${ }^{* 2}$, 吉野知子 ${ }^{2}$, 田中 剛 $2^{2}$

A marine cold tolerant diatom Mayamaea sp. JPCC CTDA0820 which showed high lipid content of $47 \%$ at $10^{\circ} \mathrm{C}$ was isolated from the coastal area of Kitakyushu city, Japan as a candidate for biodiesel production in winter in Japan. This strain can be cultured at a wide range of temperature from $5^{\circ} \mathrm{C}$ to $28^{\circ} \mathrm{C}$. The biomass productivity and the oil productivity were $31 \mathrm{~g} / \mathrm{m}^{2} /$ day and $9.8 \mathrm{~g} / \mathrm{m}^{2} /$ day at the optimized culture conditions at $10^{\circ} \mathrm{C}$, respectively. The results highly suggested that the strain JPCC CTDA0820 was appropriate for the biodiesel production in cool climates. Mayamaea sp. JPCC CTDA0820 were succeeded in outdoor mass cultivation in winter (Nov. 25- Dec. 5). With the combination of our previously reported promising biodiesel producing diatom Fistulifera solaris JPCC DA0580, the stable biodiesel production through the year can be achieved.

Key Words

Biodiesel production, Cold tolerant microalgae, Mayamaea sp. JPCC CTDA0820

冬季におけるバイオデイーゼル燃料生産の候補株として北九州沿岸から単離された耐冷性海洋珪藻 Mayamaea 属 JPCC CTDA0820 株は $10^{\circ} \mathrm{C} に$ 打いて高いオイル含有量 $(47 \%)$ を示した。本株は $5-28^{\circ} \mathrm{C}$ までの広い温度域に狲培養可能であ り，最適化した培養条件に执いて，バイオマス及びオイルの生産性は $31 \mathrm{~g} / \mathrm{m}^{2} /$ day, $9.8 \mathrm{~g} / \mathrm{m}^{2} /$ day であった。更に当該株 の屋外大量培養に成功した。これらの結果から Mayamaea 属 JPCC CTDA0820 株は, 低温環境下に扔いてバイオデイー ゼル燃料生産を可能とし，これまでにバイオデイーゼル燃料生産に用いてきた海洋珪藻 Fistulifera solaris JPCC DA0580 株と組み合わせることで，年間を通じた安定生産が可能になる。

キーワード

バイオデイーゼル生産, 耐冷性微細藻類, Mayamaea 属 JPCC CTDA0820 株

※1 Biotechnology Laboratory, Wakamatsu Research Institute, Technology Development Center,

Electric Power Development Co., Ltd.

1 Yanagasaki-machi, Wakamatsu-ku, Kitakyusyu-shi, Fukuoka, 808-0111 Japan

※2 Division of Biotechnology and Life Science, Institute of Engineering,

Tokyo University of Agriculture and Technology

2-24-16, Naka-cho, Koganei-shi, Tokyo, 184-8588 Japan
※1 電源開発株式会社 技術開発部 若松研究所 バイオ研究室 干 808-0111 福岡県北九州市若松区柳崎町 1

※2 東京農工大学大学院工学研究院 生命機能科学部門 干 184-8588＼cjkstart東京都小金井市中町 2-24-16 


\section{1. 緒 言}

近年, 石油や石炭といった化石然料の枯渇や地球温暖化 などの問題から，二酸化炭素削減効果のあるバイオ燃料が 注目を集めている。バイオ燃料はその原料となるバイオマス の種類により，第 1 世代～第 3 世代までに分類されている。 第 1 世代のバイオ燃料とは, 食物であるナタネや大豆, また はサトウキビなどを原料としている。これらの原料は主に食 料や飼料として用いられているため, 第 1 世代のバイオ燃料 は食物や飼料利用との競合, 食料価格の高騰や耕作地の競 合，更には生産工程におけるエネルギー収支が悪いなどの問 題が生じた。燃料の生産プロセスはエネルギー収支比 (EPR; energy profit ratio）で評価され，生産したエネルギー/生 産に消費したエネルギー）で示される。つまり EPR ミ1で なければ, エネルギー生産プロセスとしては成立しない。第 2 世代のバイオ燃料は第 1 世代で生じた問題点を解消するた めに，食料と競合しない木質バイオマスやバイオ燃料生産に のみ利用するヤトロファやキャッサバなどを利用し生産を行っ ている1)。これにより食料との競合などの問題は解決された が，依然として，耕作地との競合の問題や EPR の改善は不 十分であった。そこで EPRの改善を目指し, 現在では第 3 世代のバイオ燃料生産が多く行われている。第 3 世代のバ イオ燃料はバイオマスとして, 微細藻類を利用している。第 1 世代や第 2 世代のバイオマスは陸生植物であり, アメリカ の運搬用燃料の $50 \%$ を賄うためにはアメリカの耕地面積の $24 \%$ が必要であると試算されている ${ }^{2)}$ 。そこで現在では限ら れた陸地で生産するのではなく，広大な海域に着目し，15 〜 300 倍の生産性の向上が見込まれている海洋性微細藻類 がバイオ燃料生産の候補バイオマスとして注目されている2)。 しかしながら微細藻類を用いたバイオ燃料生産においても, EPRの問題は解決されておらず各プロセスの最適化などが行 われているが, 高く見積もった場合においても1程度である という現状である。

一方でエネルギー生産の実用化においては EPR 以外にも 考慮するべき点がいくつか存在する。それは二酸化炭素削 減効果, コス卜，そして供給安定性である。これらに EPR を加えた 4 つ要素をバランスよく満たすことがバイオ燃料生 産の実用化には非常に重要になってくる。微細藻類を用いた 場合, その増殖速度の速さから陸生植物を用いた場合と比 較して二酸化炭素削減効果は高い3)。またコストに関しては 培養に用いる水のリサイクルや排水等を用いることでリンや 窒素源を再利用することや $\beta$ カロテンなどの高付加価值の副 産物を生産させるなどにより全体のコストダウンが行われて いる。このように EPR, 二酸化炭素削減効果やコストといっ た要因に関してはこれまで数多くの議論や対応策が行われて いるが, 安定供給に関してはあまり考慮されていない現状で あった。バイオ燃料生産に用いられている株の多くは至適培 養温度が $20 \sim 30^{\circ} \mathrm{C}$ 付近の中温性微細藻類である。それは バイオ燃料生産を行う場所や地域が温暖な地域でのみの生 産を前提としているためである。一方で, 日本のような四季 に気候の変動が激しい場所や高緯度地域においては, 海域
の温度変化は $10 \sim 25^{\circ} \mathrm{C}$ 付近と変動が大きく中温性微細藻 類を用いた場合だと著しく生産性が低下するという試算がな されている4）気温の影響の少ない屋内での培養や温度コン トロールの導入を考えた場合, 装置の大型化や設置場所の 確保，更に投入エネルギーの増加の面から望ましくない。こ れらを考慮すると屋外での開放系, かつ粗放型の培養が最 適であるが, このような屋外培養においては他の細菌類の混 入や水温の変化など外環境の変化が大きい。そのため, 低 温環境下でかつ屋外という過酷な環境に適した株を選抜す ることが通年のバイオ燃料生産を行うためには必須である。

近年, 通年バイオ燃料生産に向けて, 低温環境下で生育 可能な好冷性・耐冷性の微細藻類がいくつか報告されてい る 5) 7)。これらの報告では培養温度域を低温〜中温域まで 幅広く持つ微細藻類を獲得し, 年間を通じた培養を行うこと を目的としている。しかしながら，これらの株はオイル含有 量が低いこと, 難培養性であることなどの問題があり屋外で の培養評価まで至っていない。

我々はこれまでにオイル高蓄積海洋珪藻 Fistulifera solaris (F. solaris) JPCC DA0580 株を獲得し, 屋外大量培養試験を 実施している ${ }^{8)}$ 。当該株はオイル含有量が 60-65\% と非常に 高く, また生産する脂肪酸はバイオデイーゼル燃料に非常に 適した組成を有していることが確認されている ${ }^{9}$ 。そこで我々 は同じ培養特性を持つ 2 種類の微細藻類を冬季〜春季, 夏 季〜秋季と使い分けることで, 生産プロセスをほとんど変え ることなく年間生産が可能になると考え, 耐冷性を有する新 規オイル高蓄積海洋珪藻株のスクリーニングを行い, 培養特 性の評価及び屋外培養への適応を行った。

\section{2. 実験方法}

\section{1 候補株のスクリーニング}

日本各地の海水をサンプリングした。回収した各サンプ ルを, 珪藻類の培養に一般的に用いられる $\mathrm{f} / 2$ 培地 ${ }^{10)}$ へ 植え継ぎ, 低温環境下 $\left(10^{\circ} \mathrm{C}\right)$ で培養を行い, 耐冷性珪藻 類のスクリーニングを行った。更にオイルを高蓄積している 株をスクリーニングするため, 培養 10 日目の細胞に対し, BODIPY505/515（Molecular Probes, Eugene, OR, USA） を 添加し, オイルボデイの蛍光染色を行った。蛍光顕微鏡を用 いて細胞内オイルボデイを観察し，低温環境下で培養可能， かつオイル高蓄積株のスクリーニングを行った。

\section{2 低温下での培養特性の評価}

候補株の低温下での培養特性の評価として培養条件 (光 量, 温度, $\mathrm{CO}_{2}$ 濃度, 栄養塩濃度) の検討, 低温でのバイ オマス生産性及びオイル含有量の評価, 及びガスクロマトグ ラフィー質量(GC-MS) 分析装置による脂肪酸組成解析を行っ た。バイオマス及びオイル含有量は以下の手法により測定し た。藻体の培養には, f/2 培地の各成分を 20 倍 (シリカの み 80 倍）に富栄養化した培地を用い, $500 \mathrm{ml}$ 容扁平フラス コを用いて, エアレーション $0.8 \mathrm{l} / 1 / \mathrm{min}\left(2 \% \mathrm{CO}_{2}\right)$, 温度 $10^{\circ} \mathrm{C}$, 光量 $140 \mu \mathrm{mol} / \mathrm{m}^{2} / \mathrm{s}$ で培養を行った。各培養条件の検討 


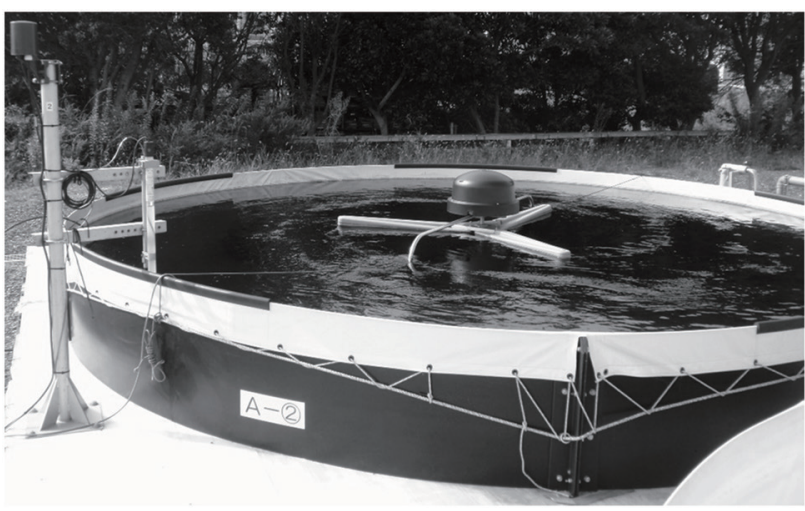

Fig. 1 Open pond reactor (Area: $20 \mathrm{~m}^{2}$, Volume : 10,000 I, Depth : $0.5 \mathrm{~m}$ )

は，上記の条件を基本培養とし，条件検討の際には対応す るパラメータのみを変更した $\left(\mathrm{CO}_{2}\right.$ 濃度 : 0-8 \%, 温度 : 5 $30^{\circ} \mathrm{C}$, 光量: $\left.70-260 \mu \mathrm{mol} / \mathrm{m}^{2} / \mathrm{s}\right)$ 。藻体を遠心回収 $(6,500 \mathrm{~g}$, 10 分間）し，ペレットを蒸留水で 2 回洗浄した後，凍結乾 燥した。得られた乾燥藻体を秤量し，バイオマス量を測定し た。乾燥藻体を乳鉢，乳棒を用いて 5 分間破砕した後, $n$ ヘキサン $5 \mathrm{ml}$ を加え, 遠心分離 $(1,000 \mathrm{~g}, 5$ 分間）した 後，上清を分取した。ペレットに対し再度へキサン $4 \mathrm{ml}$ を 添加し，同様に遠心し，回収した上清をアルゴンガス䨌囲気 下で $80^{\circ} \mathrm{C}$ に加熱し、へキサンを揮発させた。抽出物を秤量 し，乾燥藻体重量あたりのオイル含有量を算出した。GCの 条件として, カラム FAME WAX (30 m, 0.25 mm (I.D.), $0.25 \mu \mathrm{m}$ film, RESTEK, Bellefonte, PA, USA) を用いて昇温 法により分析した。昇温条件は, $140^{\circ} \mathrm{C}$ で5分間保持した後, $4^{\circ} \mathrm{C} /$ 分間で昇温し, $240^{\circ} \mathrm{C}$ で 10 分間保持した。MSのイオ ン化法として電子衝撃法を用いた。脂肪酸の標品として 37 component FAME standard (Sigma Aldrich, MO, U.S.) を用い, 同様に GC-MSにより分析を行った。

\section{3 屋外における実証試験}

電源開発 (株)の若松研究所 (福岡県北九州市) において, 当該株を用いた屋外培養を以下の培養条件で行った。Open pond 型培養槽 (底面積: $20 \mathrm{~m}^{2}$, 水面の高さ: $50 \mathrm{~cm}$, 容積 : 10,000 1）（Fig. 1)，f/2 培地のシリカ濃度を4倍にした改変 $\mathrm{f} / 2$ 培地, 初期藻体濃度 $0.05 \mathrm{~g} / \mathrm{l}$, 通気処理無し, 浮遊型 の擋拌装置を用いて 2014/11/25～2014/12/5 の 10 日間培 養を行った。

\section{3. 結果及び考察}

\section{1 候補株のスクリーニング}

海水サンプルを 1 週間培養した結果, 70 コロニーを獲得 した。これらの候補株を培養し, 蛍光顕微鏡を用いてオイ ル含有量の高い株をスクリーニングした結果，北九州市沿 岸の海水から JPCC CTDA0820 株が選抜された（Fig. 2)。 当該株は細胞内に 2 つオイル蓄積オルガネラであるオイ ルボデイを持ち、これまでに獲得しているF. solaris JPCC

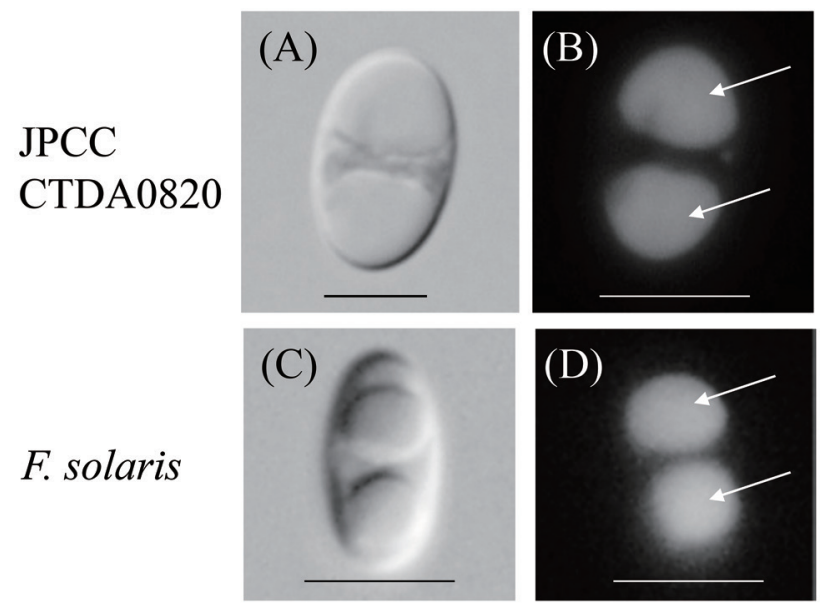

Fig. 2 Microscopic images of $F$. solaris JPCC DA0580 and JPCC CTDA0820 stained with BODIPY 505/515. Arrows indicate oil body

(A),(C): Differential interference contrast (DIC) images

(B),(D): Fluorescent images. Scale bars $=10 \mu \mathrm{m}$

DA0580 株と非常に似た形態を持つことが確認できた。また 18S rDNA 配列から分子系統解析を行った結果，当該株は 羽状目珪藻 Mayamaea 属と相同性 $99 \%$ を示し, Mayamaea 属 であることが示唆された。

\section{2 低温下での培養特性の評価}

\subsection{1 至適培養条件 (屋内環境) の検討}

培養条件として至適光量, 培養温度, $\mathrm{CO}_{2}$ 濃度, 栄養 塩濃度の検討を行った結果をまとめた（Table 1)。F. solaris JPCC DA0580株と比較するとシリカと $\mathrm{CO}_{2}$ の要求性が高いこ とが確認された。つまりシリカ濃度以外に培養特性に大差が ないことが確認された。低温下 $\left(10^{\circ} \mathrm{C}\right)$ と至適培養温度 $\left(25^{\circ} \mathrm{C}\right)$ でのバイオマス生産性及びオイル含有量の測定を行った結 果, $10^{\circ} \mathrm{C}$ 及び $25^{\circ} \mathrm{C}$ に打いてそれぞれ $270 \mathrm{mg} / 1$ 及び $307 \mathrm{mg} / 1$, オイル含有量はそれぞれ $47 \%$ 及び $60 \%$ であった。このこと から至適条件よりは低下するものの，十分なバイオマス生産 性及びオイル含有量を有していることが確認できた。またこ れまで用いているF. solaris JPCC DA0580 株よりも低光量で も生育が可能であるという特徵を有しており，これにより培 養槽を深くすることが可能であり単位面積当たりの生産性向 上に寄与できると考えられた。

更に低温での脂肪酸組成を解析した結果，主な脂肪酸組 成はパルミチン酸 $(\mathrm{C} 16: 0)$ ，パルミトレイン酸（C16:1），ステ アリン酸 (C18:0)，オレイン酸 (C18:1) であり，全脂肪酸の 70\%を占めることが示された (Table 2)。またバイオディーゼ ル燃料の品質低下に繋がる不飽和結合数の増加や炭素鎖長 の変化など，温度変化による大きな変化は見られなかった。 よって当該株は低温下に扔いてもバイオ燃料生産に適した脂 肪酸を合成可能な株であることが示された。 
Table 1 Comparison of selected traits of $F$. solaris JPCC DA0580 and JPCC CTDA0820

\begin{tabular}{lcc}
\hline Growth characteristics & JPCC CTDA0820 & F. solaris JPCC DA0580 \\
\hline Optimum temperature $\left({ }^{\circ} \mathrm{C}\right)$ & 25 & 25 \\
Growth at $10{ }^{\circ} \mathrm{C}$ & + & - \\
Optimum light intensity $\left(\mu \mathrm{mol} / \mathrm{m}^{2} / \mathrm{s}\right)^{*}$ & 140 & 500 \\
Optimum $\mathrm{CO}_{2}(\%)^{* *}$ & 4 & 2 \\
Maximum oil content $(\%)$ & $60\left(25^{\circ} \mathrm{C}\right) ; 47\left(10^{\circ} \mathrm{C}\right)$ & $65\left(25^{\circ} \mathrm{C}\right)$ \\
N:P:Si $(\mathrm{mol})$ & $24: 1: 12$ & $24: 1: 3$ \\
Biomass productivity $\left(\mathrm{g} / \mathrm{m}^{2} / \text { day }\right)^{* 2}$ & 31 & 64 \\
Oil productivity $\left(\mathrm{g} / \mathrm{m}^{2} / \mathrm{day}\right)^{* 2}$ & 9.8 & 23.9 \\
\hline
\end{tabular}

* Medium: modified 10f medium.

${ }^{* * *}$ Mayamaea sp. cultivated at $10{ }^{\circ} \mathrm{C}$, F . solaris JPCC DA0580 cultivated at $25{ }^{\circ} \mathrm{C}$. Both diatoms cultivated in modified $\mathrm{f}$ medium at $140 \mu \mathrm{mol} / \mathrm{m}^{2} / \mathrm{s}$.

Table 2 Fatty acids composition of Mayamaea sp. JPCC CTDA0820 under the cold temperature

\begin{tabular}{ccc}
\hline & \multicolumn{2}{c}{ Cultivation temperature } \\
Fatty acids & $10^{\circ} \mathrm{C}$ & $25^{\circ} \mathrm{C}$ \\
\hline $\mathrm{C} 12: 0$ & $1.6 \pm 2.6$ & $1.8 \pm 3.1$ \\
$\mathrm{C} 14: 0$ & $7.0 \pm 1.4$ & $8.6 \pm 2.5$ \\
$\mathrm{C} 15: 0$ & $2.5 \pm 1.7$ & $3.8 \pm 1.6$ \\
$\mathrm{C} 16: 0$ & $16.3 \pm 4.6$ & $15.8 \pm 2.3$ \\
$\mathrm{C} 16: 1$ & $40.8 \pm 18.9$ & $34.7 \pm 6.2$ \\
$\mathrm{C} 17: 0$ & $1.0 \pm 1.5$ & $0.8 \pm 1.4$ \\
$\mathrm{C} 17: 1$ & $1.0 \pm 1.4$ & $1.8 \pm 1.6$ \\
$\mathrm{C} 18: 0$ & $1.6 \pm 2.5$ & $6.1 \pm 2.7$ \\
$\mathrm{C} 18: 1 \mathrm{c}$ & $8.2 \pm 6.3$ & $6.6 \pm 5.9$ \\
$\mathrm{C} 18: 1 \mathrm{t}$ & $4.3 \pm 3.4$ & $6.9 \pm 3.1$ \\
$\mathrm{C} 18: 2 \mathrm{c}$ & $2.7 \pm 1.5$ & $0.8 \pm 1.4$ \\
$\mathrm{C} 18: 2 \mathrm{t}$ & $2.0 \pm 1.5$ & $0.7 \pm 1.2$ \\
$\mathrm{C} 18: 3$ & $2.4 \pm 1.2$ & $3.3 \pm 1.4$ \\
$\mathrm{C} 20: 0$ & $1.5 \pm 2.5$ & - \\
$\mathrm{C} 20: 2$ & $1.2 \pm 2.0$ & - \\
$\mathrm{C} 20: 3$ & $2.1 \pm 1.8$ & $3.6 \pm 1.5$ \\
$\mathrm{C} 20: 5$ & $4.2 \pm 0.4$ & $4.7 \pm 1.1$ \\
\hline
\end{tabular}

\section{3 屋外での実証試験}

本培養装置は EPR の向上を目指し，投入するエネルギー を削減している。擋拌には浮遊式擋拌装置を用いることで, 培養容積に対する投入エネルギーの大幅な削減が可能であ り，現状用いているF. solaris JPCC DA0580 株においては $\mathrm{EPR}>1.5$ が見込まれている。また $\mathrm{CO}_{2}$ 供給は培地の $\mathrm{pH}$ 制御する目的でわずかに供給しているが，温度制御，装置及 び培地の滅菌操作, 光照射などは行っていない。本培養期間 (2014/11/25～2014/12/5) に扔いて, 平均水温は $11.6{ }^{\circ} \mathrm{C}$ （4.3〜 $18.7^{\circ} \mathrm{C}$ ) であった。前培養した藻体を初期濃度 0.05 $\mathrm{g} / 1$ で植え継ぎし，培養 10 日間でバイオマス量は $0.15 \mathrm{~g} / 1$ に到達することが確認された。また，当該株は，11月～3 月の冬季の屋外培養試験を実施し, 培地等の滅菌処理など 行わず他の細菌の混入などの影響を受けても，屋外で優先 的に増殖し，大量培養が可能であることが示された。しか しながら, F. solaris JPCC DA0580 株と比較するとバイオマ ス及びオイル生産性の低下が見られた。これは低温下での培
養であることが大きな原因の1つであることに加え, その他 に, JPCC CTDA0820 株が $\mathrm{CO}_{2}$ の要求量が F. solaris 株より も高いことに由来することも考えられた。今後は EPR を考慮 しながら， $\mathrm{CO}_{2}$ の添加を行うなどして生産性と EPR のバラン スの取れるシステムに改良する必要がある。

\section{4. 結 言}

本研究ではバイオデイーゼル燃料の安定供給を目指し好・ 耐冷性オイル高蓄積珪藻のスクリーニングを行った。その結 果, 5-28 ${ }^{\circ} \mathrm{C}$ まで培養可能な Mayamaea 属 JPCC CTDA0820 株を選抜した。JPCC CTDA0820株は低温環境下においても， 十分なバイオマス生産性及びオイル含有量を有していること が確認できた。更に 11 月〜 3月で屋外培養試験を実施し, 屋外培養可能であることを明らかにした。さらに，低温下 での培養特性を評価した結果, シリカの要求性がF. solaris JPCC DA0580 株よりも高く, 組み合わせた生産プロセスを 構築するためには, 僅かに培地を改変する必要性がある一 方で, F. solaris JPCC DA0580 株よりも至適光量が低いため, 高層化培養が可能であるといった特徵を有していることが確 認された。

本研究ではこれまであまり評価されていない安定供給とい う面に着目し，耐冷性を有するオイル高蓄積珪藻をスクリー ニングした。低エネルギー化した屋外培養システムへ応用し， 屋外での大量培養への適応の可能性を示した。本結果より これまで用いているF. solaris JPCC DA0580 株と組み合わせ たバイオデイーゼル燃料の年間生産プロセスの基盤技術が 構築できた。

\section{謝 辞}

本研究は, 新エネルギー・産業技術総合開発機構 (NEDO) の戦略的次世代バイオマスエネルギー利用技術開発事業 (次 世代技術研究開発）の助成を受けたものである。

\section{文 献：References}

1) Inderwildi, O. R.; King, D. A., Energy Environ. Sci., 2, 343346 (2009)

2) Yusuf, C., Biotechnol. Adv., 25, 294-306 (2007) 
3) Batan, L.; Quinn, J.; Willson, B.; Bradley, T., Environ. Sci. Technol., 44, 7975-7980 (2010)

4) Slegers, P. M.; Lösing, M. B.; Wijffels, R. H.; van Straten, G.; van Boxtel, A. J. B., Algal Res., 2, 358-368 (2013)

5) Ahn, J.-W.; Hwangbo, K.; Lee, S. Y.; Choi, H.-G.; Park, Y.I.; Liu, J. R.; Jeong, W.-J., Bioresour. Technol., 125, 340-343 (2012)

6) Nelson, D. R.; Mengistu, S.; Ranum, P.; Celio, G.; Mashek,
M.; Mashek, D.; Lefebvre, P. A., Biotechnol. Prog., 29, 853861(2013)

7) Jin, X.; Hu, H., Bioresour. Technol., 144, 637-643 (2013)

8) Sato, R.; Maeda, Y.; Yoshino, T.; Tanaka, T.; Matsumoto, M., J. Biosci. Bioeng., 117, 720-724 (2014)

9) Liang, Y.; Maeda, Y.; Yoshino, T.; Matsumoto, M.; Tanaka, T., Mar. Drugs., 12, 3218-3230 (2014)

10) Guillard, R. R. L., Cult. Mar. Invertebr. Anim., 29-60 (1975) 